\title{
Spatial and temporal patterns of benthic invertebrates in the Tagus estuary, Portugal: comparison between subtidal and an intertidal mudflat
}

\author{
SUSANA FRANÇA ${ }^{1}$, CATARINA VINAGRE $^{1}$, MIGUEL A. PARDAL ${ }^{3}$ \\ and HENRIQUE N. CABRAL ${ }^{1,2}$ \\ ${ }^{1}$ Instituto de Oceanografia, Faculdade de Ciências da Universidade de Lisboa, Campo Grande, 1749-016 Lisboa, Portugal. \\ E-mail: sofranca@fc.ul.pt \\ ${ }^{2}$ Departamento de Biologia Animal, Faculdade de Ciências da Universidade de Lisboa, Campo Grande, 1749-016 Lisboa, \\ Portugal. \\ ${ }^{3}$ IMAR - Institute of Marine Research, Department of Zoology, University of Coimbra, 3004-517 Coimbra, Portugal.
}

SUMMARY: Intertidal mudflats are a dominant feature in many estuarine systems and may be a significant component of the feeding grounds available for many fish and bird species. Therefore, it is crucial to determine the importance and role that this particular habitat plays for the different estuarine communities. Spatial and temporal dynamics of macrobenthic communities in an intertidal mudflat of the Tagus estuary were assessed in order to determine the role of this habitat in the whole estuarine functioning. Benthic macroinvertebrate communities were sampled monthly in two intertidal areas (upper and lower) and in the adjoining subtidal area for one year. Macroinvertebrate density and biomass in the intertidal mudflat were higher than in the subtidal area, but no clear trends were found between the lower and upper intertidal area. Spatial patterns in the community were more pronounced than seasonal patterns. This benthic community was characterised by high densities of Pygospio elegans, Scrobicularia plana, Cyathura carinata, Hydrobia ulvae and Nereis diversicolor. Abundance and biomass values in this intertidal mudflat were considered low in comparison with other estuarine habitats, namely seagrass beds. Nevertheless, this habitat plays an important role for the main species present in the community, acting as a key area for recruitment, with high concentrations for many invertebrate species.

Keywords: benthic macroinvertebrates, community structure, intertidal mudflat, subtidal, Tagus estuary.

RESUMEN: PAUTAS DE DISTRIBUCIÓN ESPACiO TEMPORALES DE INVERTEBRADOS BENTÓNICOS EN EL ESTUARIO DEL TAJO, PORTUGAL: COMPARACIÓN ENTRE MARISMAS INTERMAREALES Y SUBMAREALES. - Las marismas intermareales son características de muchos sistemas estuáricos y pueden abarcar un componente significativo de las áreas de alimentación disponibles para muchas especies de peces y aves. Por tanto, es crucial determinar la importancia y el papel que juega este hábitat para las diferentes comunidades estuarinas. Se evaluaron las dinámicas espaciales y temporales de las comunidades macrobentónicas en una marisma intermareal del estuario del Tajo, determinando el papel de este hábitat en el conjunto del funcionamiento de estuario. Las comunidades de macroinvertebrados bentónicos se muestrearon, mensualmente durante un año, en dos áreas intermareales (superior e inferior) y en las áreas submareales adyacentes. La densidad y la biomasa de los macroinvertebrados en las marismas intermareales fueron superiores que en el área submareal, y no se encontraron claras tendencias entre el intermareal superior e inferior. Los patrones espaciales en la comunidad fueron más pronunciados que los estacionales. Esta comunidad bentónica estuvo caracterizada por altas densidades de Pygospio elegans, Scrobicularia plana, Cyathura carinata, Hydrobia ulvae y Nereis diversicolor. Los valores de abundancia y biomasa en esta marisma intermareal fueron considerados bajos cuando se comparan con otros hábitats estuarinos como las praderas de fanerógamas. No obstante, este hábitat juega un importante papel para las principales especies presentes en la comunidad, actuando como un área clave para el reclutamiento, con altas concentraciones de muchas especies de invertebrados.

Palabras clave: macroinvertebrados bentónicos, estructura de la comunidad, marismas intermareales, submareales, estuario del Tajo. 


\section{INTRODUCTION}

Coastal transition ecosystems such as estuaries and coastal lagoons are recognised worldwide as the most productive and valuable aquatic ecosystems on Earth (Costanza et al., 1997). These transitional environments are characterised by a unique biodiversity and perform several vital functions, e.g. as nursery areas for fish, feeding areas for migrating and wintering birds and migration routes for anadromous and catadromous fish (Odum, 1983; McLusky, 1989).

One of the most important characteristics of estuaries is the fact that they form a mosaic of inter-linked habitats that should not be considered in isolation (Morrisey et al., 2003). Each one is of particular value for the different species that use it. The assessment of the importance, dynamics and functions of each estuarine habitat, as well as their ecological connectivity, is still poorly understood (Elliott and Hemingway, 2002).

Intertidal mudflats are a dominant habitat in many estuarine systems, often covering a considerable part of their area (Morrison et al., 2002). They have long been recognised as a key habitat for the estuarine food web because of their disproportionately high productivity in comparison with subtidal areas (Reiser, 1985; Michaelis et al., 1992; Wanink and Zwarts, 1993; Elliott and Dewailly, 1995), and an increasing number of studies considering their dynamics have been published recently (Dittmann, 2000; Boer and Prins, 2002; Dolbeth et al., 2003; Melville and Connolly, 2005; Rodrigues et al., 2006; Cardoso et al., 2008).

The first studies on intertidal mudflats focused mainly on macro benthic communities, so their distribution in this habitat is well known for temperate areas (Dittman, 2000). The spatial heterogeneity of macrobenthos along the estuarine gradient is traditionally described in relation to salinity and sediment composition (Ysebaert et al., 2003). However, the depth gradient from high intertidal to deep subtidal areas also has a pronounced effect on macrobenthic species distribution within the estuary (Ysebaert et al., 2002), with the highest values for density and biomass being registered at intertidal sites (Ysebaert et al., 2000). Intertidal mudflats also play an important role as a preferential recruitment habitat for several macroinvertebrate species when adjacent seagrass habitats are available and show higher species richness and abundances (Heck et al., 1995).
The present study was conducted in the Tagus estuary, one of the largest estuaries on the Atlantic coast of Europe. Despite being subjected to intense human disturbance, the Tagus estuary contains a high biodiversity, mainly because many different habitats are available for biological communities (Bettencourt et al., 2001). Intertidal mudflats occupy $40 \%$ of the total estuarine area and are mainly located within the nature reserve of the Tagus estuary. They are used as feeding areas, maintaining large populations of resident and migratory birds (Moreira,1999). The Tagus estuary plays a functional role as a nursery area for many commercially important fish species (Costa and Bruxelas, 1989; Costa and Cabral, 1999), with intertidal mudflats maintaining suitable conditions for this nursery function, as previously reported for this area (Cabral, 2000; Vinagre et al., 2006; França et al., 2008).

Despite the recognised importance of the benthic macrofauna of these areas, the most extensive study on the Tagus estuary intertidal benthic macroinvertebrates, which dates from the early 1980s (Calvário, 1982), is qualitative and fails to cover the most important areas. Recent studies on this area described the structure of the benthic invertebrate community and evaluated its relationship with several environmental factors and the dynamics of this community (Rodrigues et al., 2006; Silva et al., 2006). However, none of these studies dealt with the importance of this vertical gradient from high intertidal to subtidal areas and the differences between their communities.

In this study both intertidal and subtidal habitats were sampled, with the main goal of determining the assemblage structure and the spatial and seasonal distribution of macrobenthic communities in the upper and lower part of the intertidal mudflat and in the subtidal area adjacent to it. Special emphasis is placed on differences between communities through this tidal gradient. The crucial role that this intertidal mudflat plays in the global dynamics and functioning of the Tagus estuary is also discussed.

\section{MATERIAL AND METHODS}

\section{Study Area}

The Tagus estuary $\left(38^{\circ} 40^{\prime} \mathrm{N} 9^{\circ} 15^{\prime} \mathrm{W}\right)$ is $50 \mathrm{~km}$ long and occupies an area of $325 \mathrm{~km}^{2}$. The system has a tidal amplitude of $4 \mathrm{~m}$ and the intertidal 


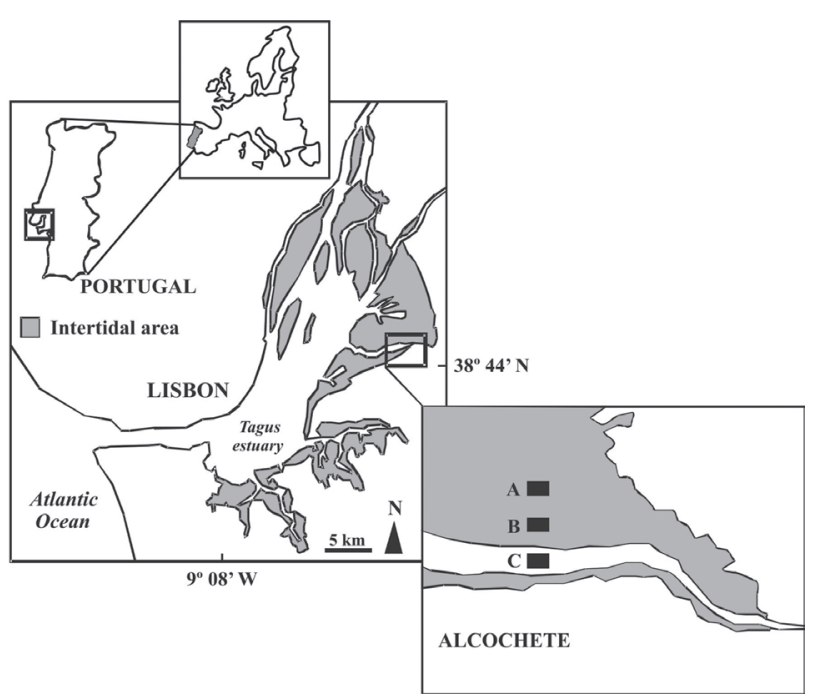

FIG. 1. - Location of sampling areas in the Tagus estuary: A, upper intertidal; B, lower intertidal; C, subtidal.

and saltmarsh areas account for $40 \%$ of the total estuarine area (Bettencourt et al., 2001). The average estuarine depth is $c a .10 \mathrm{~m}$ and the maximum depth is $40 \mathrm{~m}$ near the mouth of the estuary. The river flow varies both seasonally and annually, with a mean discharge of $400 \mathrm{~m}^{3} \mathrm{~s}^{-1}$ (Bettencourt and Ramos, 2003).

The Tagus estuary includes several special areas that are protected because of their biological diversity, one of the most important being the Tagus Estuary Nature Reserve, with an area of 14560 ha (Farinha et al., 2001). This area is mainly composed of mudflats that become emerged at low tide, playing an important role as feeding grounds for wintering birds that use the area as a stopover site during their winter migrations (Moreira, 1999).

The present study was undertaken at an area located in the upper estuary in a sheltered south branch, located near Alcochete (Fig. 1). The study sites are located in a large mudflat intertidal area, with an adjacent channel representing the subtidal area. These mudflat areas are completely drained for two periods daily.

According to the elevation of the two intertidal sampled areas, the mean emersion times for both areas were calculated using the synoptic equations for the water level. The obtained estimations were 17 hours day ${ }^{-1}$ for the upper part of the mudflat and 14 hours day ${ }^{-1}$ for its lower part. The subtidal area (channel) is always submerged.

Salinity in this area varies from 4 in winter to nearly 30 in summer, while water temperature ranges from 8 to $26^{\circ} \mathrm{C}$ (Cabral et al., 2001).

\section{Sampling and laboratory procedures}

Quantitative sampling of macrobenthic organisms was carried out monthly from January to December 2004, covering three main areas: upper intertidal (A), low intertidal (B) and subtidal (C). Samples were taken during high water, at neap tides. In each area 10 replicates were randomly sampled using a Van Veen grab $\left(0.05 \mathrm{~m}^{2}\right)$. In a preliminary study in the same area, the number of replicates per sample was established using the rank-frequency diagram method (Frontier, 1983) for stabilising variability. All samples were sieved using a $0.5 \mathrm{~mm}$ mesh size sieve and fixed in $10 \%$ formalin solution. A sediment sample was obtained for determination of grain size composition.

In the laboratory samples were sorted after being stained with rose Bengal and organisms were counted and identified to the lowest taxonomic level. Measures were taken from the most abundant species: total shell length for the bivalve Scrobicularia plana (da Costa, 1778) and total body length for the worm Nereis diversicolor (O.F. Muller, 1776) and for the isopod Cyathura carinata (Krøyer, 1847). Biomass values were determined as gram ash free dry weight (g AFDW), directly measured as the difference between the dried $\left(80^{\circ} \mathrm{C}\right.$ for minimum $\left.48 \mathrm{~h}\right)$ and ashed $\left(560^{\circ} \mathrm{C}\right.$ for $\left.2 \mathrm{~h}\right)$ weight.

In order to obtain grain size composition, sediment samples were dried at $60^{\circ} \mathrm{C}$ and a $100 \mathrm{~g}$ subsample was wet-sieved through a $0.063 \mathrm{~mm}$ mesh sieve and dried. The remaining sediment was sieved through a four-sieve column. The weight of the residue remaining in each sieve was then expressed as a percentage of the initial subsample weight and the $<0.063 \mathrm{~mm}$ fraction was calculated from the difference between the initial subsample weight and the sum of the other fractions. The following categories of grain size were considered: mud $(<0.063)$, fine sand $(0.063-0.125 \mathrm{~mm})$, medium sand $(0.125-0.500$ $\mathrm{mm})$, coarse sand $(0.500-2.000 \mathrm{~mm})$ and gravel (>2.000 mm).

\section{Data analysis}

All macrobenthic abundance data were expressed as number $\mathrm{m}^{-2}$ (ind $\mathrm{m}^{-2}$ ) and biomass data as $\mathrm{g}$ Ash Free Dry Weight $\mathrm{m}^{-2}$ (g AFDW $\mathrm{m}^{-2}$ ). Most individuals were determined to species level.

The biological data for each area (a total of ten replicates per month) were considered as a single 
TABLE 1. - Sediment grain size of the three sampled areas (\%).

\begin{tabular}{lccccc}
\hline & Gravel & Coarse & Fand & Mud \\
& $(>2 \mathrm{~mm})$ & $\begin{array}{c}\text { Medium } \\
(0.125-0.5 \mathrm{~mm})\end{array}$ & $(0.063-0.125 \mathrm{~mm})$ & $(<0.063 \mathrm{~mm})$ \\
\hline Upper intertidal & 0.04 & 0.51 & 0.14 & 0.36 & 98.95 \\
Low intertidal & 0.29 & 0.33 & 0.13 & 0.82 & 98.44 \\
Subtidal & 29.76 & 40.27 & 0.04 & 0.58 & 29.35 \\
\hline
\end{tabular}

station for analysis. The aim of the analysis was to investigate the distribution patterns of species in the three areas considered (upper intertidal, low intertidal and subtidal), and to determine the differences in the spatial and seasonal changes in the community structure between them throughout the sampling year. In order to describe these differences the biological data were submitted to correspondence analysis, using CANOCO 4.5 software (Ter Braak and Šmilauer, 2002).

\section{RESULTS}

\section{Sediment analysis}

Mud was the predominant fraction found on the intertidal mudflat (Table 1). The annual mean percentage of mud in the upper intertidal area was $98.9 \%$. Similar percentages of mud were found in the lower part of the intertidal mudflat, with a yearly mean value of $98.4 \%$ (Table 1). The subtidal area sediment was primarily composed of coarse sand (40.3\%), followed by gravel and mud, which represented $29.8 \%$ and $29.4 \%$ of the total sediment, respectively.

\section{Macrofauna analysis}

During the present study, a total of 8 species and three higher taxa groups were recorded among 58 778 individuals collected from 360 samples. Some individuals were identified only to genus (particularly amphipods), while other organisms, such as oligochaetes, were only identified to class level and may have consisted of more than one species. Mean density (ind $\mathrm{m}^{-2}$ ) and biomass (g AFDW $\mathrm{m}^{-2}$ ) values for each species in the three sampled areas are presented in Table 2.

The macrobenthic community of the study area was characterised mainly by high densities of four taxa: Scrobicularia plana, Pygospio elegans, Oligo- chaeta and Cyathura carinata. Although showing marked seasonal changes, these taxa remained the dominant ones throughout the sampling period. The bivalve S. plana accounted for $45.4 \%$ of the total abundance of benthic macroinvertebrates in the upper intertidal. The polychaetes $P$. elegans also showed high densities in this particular habitat, accounting for $33.58 \%$ of the total abundance registered (Table 2). In the lower intertidal area the same species dominated the community, with $41.25 \%$ and $29.74 \%$ of the total number of individuals, respectively. In the subtidal area the oligochaeta group accounted for $47.44 \%$ of the density of the whole community (Table 2).

Table 2 shows that the bivalve Scrobicularia plana dominated the macrobenthic community, accounting for $94.57 \%, 91.53 \%$ and $89.22 \%$ of the total biomass registered in the upper and lower intertidal and subtidal habitats, respectively.

The intertidal mudflat areas showed extremely high density values for the macrobenthic invertebrate species, especially in comparison with subtidal areas, where densities were always low and relatively constant during the sampling period. The highest densities were found in the upper intertidal area during almost the whole year. An exception occurred in November, when highest densities were recorded in the lower part of the intertidal mudflat (Fig. 2). Although a peak in the community's biomass occurred in March in the upper intertidal area, the highest biomass values were always recorded in the lower intertidal area for the rest of the year. Finally, the lowest biomass values were recorded in the subtidal area throughout the year (Fig. 2).

\section{Spatial and seasonal patterns}

Density and biomass of the most important species were analysed in order to assess their seasonal and spatial patterns in the three habitat types considered. 


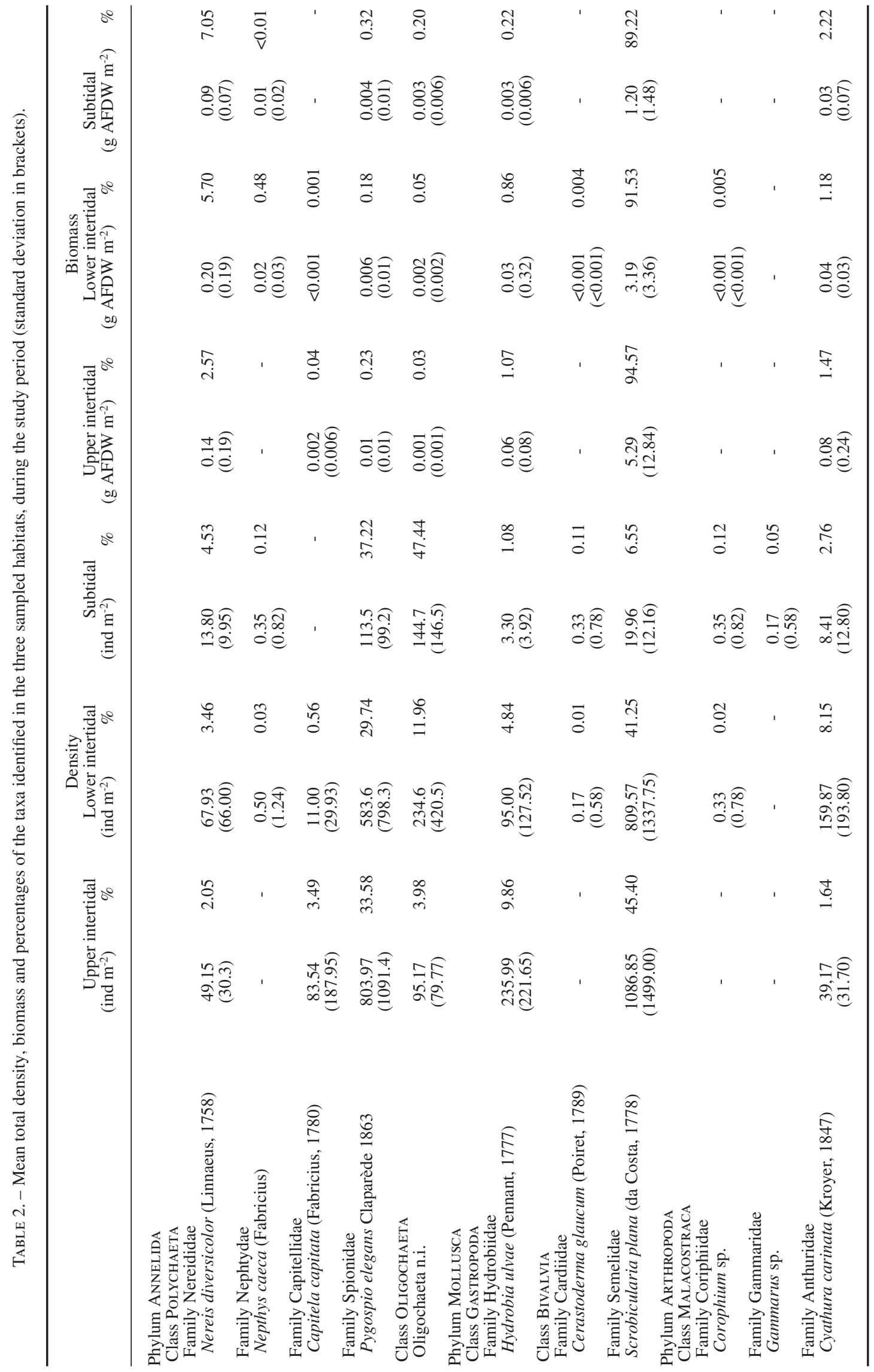




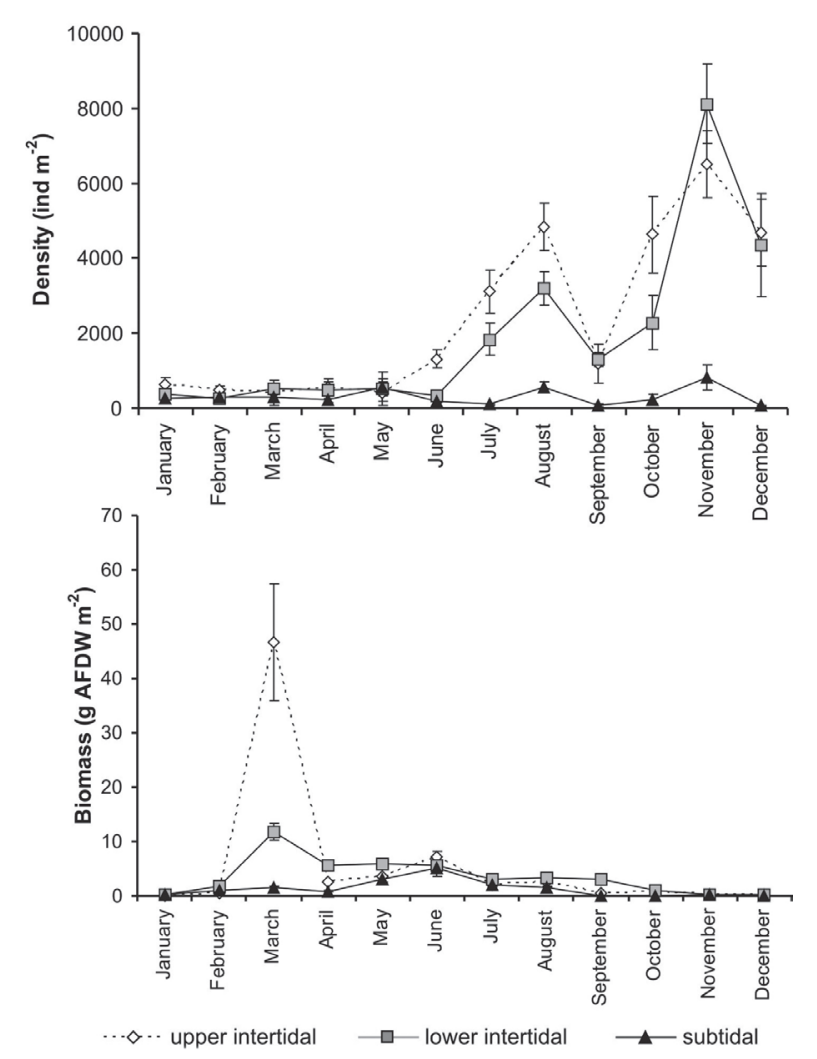

FIG. 2. - Spatial and seasonal density and biomass patterns (mean values with standard errors) of macroinvertebrates from the study area.

One of the dominant species of this community was the bivalve Scrobicularia plana. Density values for this species were higher in the upper intertidal habitat. The subtidal habitat accounted for lower density values throughout the year (Fig. 3a). Higher density peaks were obtained in November in both intertidal areas, with a mean density value of 3972 ind. $\mathrm{m}^{-2}$ for the lower intertidal area and 3887 ind. $\mathrm{m}^{-2}$ for the upper one. Despite the high number of individuals recorded in November, the highest biomass values occurred in March (45.6 $\mathrm{g} \mathrm{AFDW} \mathrm{m}^{-2}$ ) in the upper intertidal area (Fig. 3a). Figure 4a shows that these density peaks include a large number of small individuals (mean total length values of 3.8 and $4.4 \mathrm{~mm}$ between October and December). Small individuals were found mainly on the upper intertidal mudflat, while larger individuals were distributed over the lower intertidal and subtidal areas, occurring mostly during spring and summer.

The pattern observed for the isopod Cyathura carinata was similar to the afore-mentioned one but the highest densities always occurred on the lower intertidal mudflat (Fig. 3b). The density peak for this species occurred in late summer, with mean densi- ties reaching 640 ind $\mathrm{m}^{-2}$. The highest biomass value was reached in March in the upper intertidal area (0.87 $\mathrm{g} \mathrm{AFDW} \mathrm{m}^{-2}$ ) (Fig. 3b). Seasonal variations in individual total length were similar for both intertidal mudflat areas, showing an increase in spring and a decrease thereafter. The smallest individuals were found in late summer (Fig. 4b).

The polychaete Pygospio elegans was also one of the dominant species for this community and it showed a broader distribution in the intertidal mudflat, being present in much lower numbers in the subtidal (Fig. 3c). Density values for this species showed one peak in the upper intertidal mudflat in August (3664 ind $\mathrm{m}^{-2}$ ) and one in the lower intertidal mudflat in November (2658 ind $\mathrm{m}^{-2}$ ). The biomass values of this species varied during the year, with the highest values of $0.05 \mathrm{~g} \mathrm{AFDW} \mathrm{m}^{-2}$ and $0.045 \mathrm{~g}$ AFDW m ${ }^{-2}$, measured in April and August respectively, in the upper intertidal mudflat.

The polychaete Nereis diversicolor showed a wider distribution throughout the year in the three habitats, but the highest numbers of this species were always found on the intertidal mudflat. The highest density value was recorded in August, in the lower intertidal area (236 ind $\mathrm{m}^{-2}$ ) (Fig. 3d). Biomass values showed a different seasonal pattern from those of the previously-mentioned species: in the three studied areas, the highest biomass values were obtained during summer, with maximum values of $0.70 \mathrm{~g} \mathrm{AFDW} \mathrm{m}^{-2}$ in June in the upper intertidal area and $0.73 \mathrm{~g} \mathrm{AFDW} \mathrm{m}^{-2}$ in August in the lower intertidal area (Fig. 3d). The seasonal variation of the length of the individuals was similar in the three study areas. The individual mean total length showed its lowest value in January $(5.79 \mathrm{~mm})$, which was not coincident with the highest density peak recorded (Fig. $4 c)$. The smallest individuals were frequently found in the lower intertidal area and larger individuals in the subtidal area (Fig. 4c).

\section{Macrobenthic community structure}

The correspondence analysis performed to reveal the macrobenthic community structure throughout the year, using the taxa densities, accounted for $81.7 \%$ of the total variance calculated for the first two ordination axes.

The correspondence analysis revealed that differences found in the macrobenthic community structure were more pronounced in a spatial perspective when based on the density values. The subtidal area 

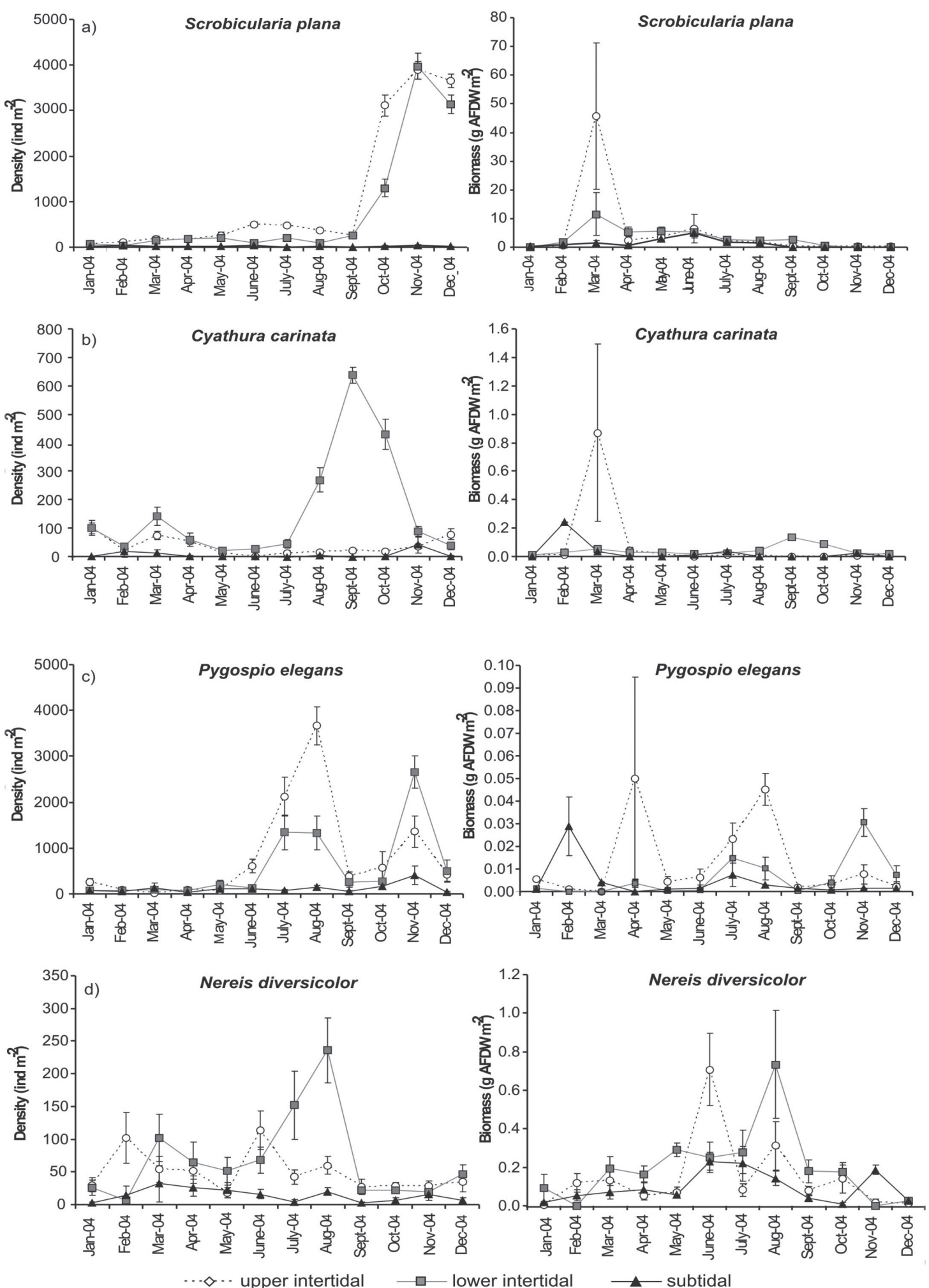

FIG. 3. - Seasonal and spatial density and biomass patterns (mean values with standard errors) of some macroinvertebrate species from the study area (a, Scrobicularia plana; b, Cyathura carinata; c, Pygospio elegans; d, Nereis diversicolor).

is almost completely distinct from the intertidal areas, as it has a very low number of species and lower density values. Gammarus sp. was the only taxon particularly associated with the subtidal area, mainly because its presence was limited to that particular area. In the intertidal areas, the upper intertidal area 

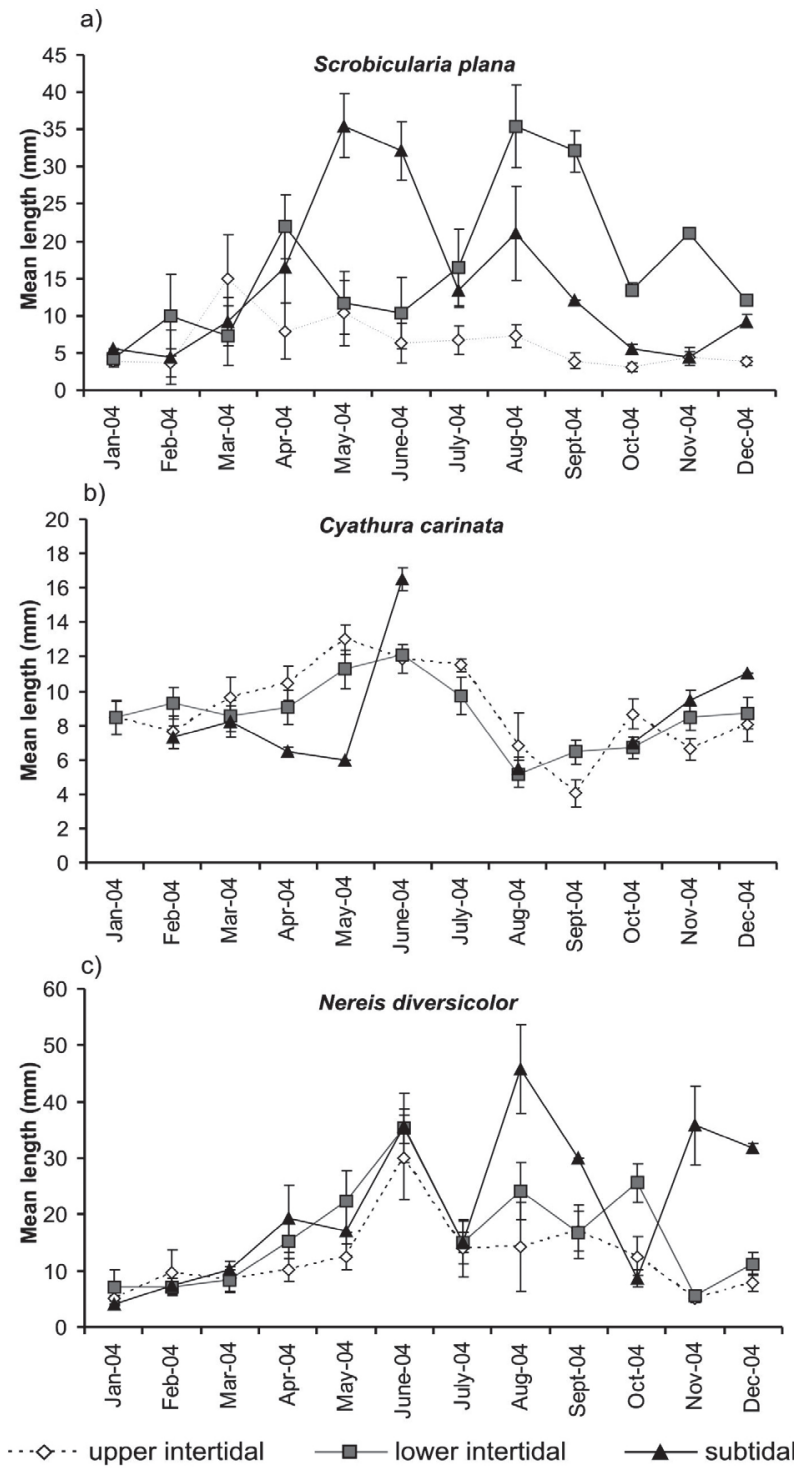

FIG. 4. - Spatial and seasonal variation pattern of individual mean total length (mm) (and standard errors) for S. plana (a), C. carinata (b) and N. diversicolor (c).

was differentiated in summer and autumn by high densities of a small number of species. The bivalve Scrobicularia plana was always dominant in the intertidal areas, showing high densities throughout the year and reaching maximum values during the autumn and winter months (Fig. 5a).

The correspondence analysis plot based on the species biomass is shown in Figure $5 \mathrm{~b}$. The total variance accounted by the first two axes was $85.6 \%$. Differences were found in the community structure at a seasonal level. The autumn points in the diagram are clearly separated from those of the other seasons and also from each other towards the extremes of the diagonal of the plot. Hydrobia ulvae is particularly associated with winter points, as the other species, especially S. plana, have higher biomass values during the spring and summer months.

\section{DISCUSSION}

The present study is the first one conducted in the Tagus estuary aiming to describe the intertidal mudflat and subtidal channel macrobenthos communities, their structure and their dynamics. Few studies have analysed the zonation from high intertidal to deep subtidal sites (Elliott and Taylor, 1989) and generally they deal mainly with only one of these habitats, making comparisons between them impossible.

This study's results have shown that throughout the sampling period, density and biomass values of the macroinvertebrate benthic communities were always much higher on the intertidal mudflat than in its adjacent subtidal area. The distinction between the upper and the lower parts of the intertidal mudflat was not particularly clear.

The mudflat areas of the Tagus estuary showed fewer species than other European estuaries (Michaelis et al., 1992; Ysebaert et al., 1998; Ysebaert et al., 2000; Dewicke et al., 2003; Laine, 2003). The number of macroinvertebrate taxa registered on the sampled intertidal mudflat (12) was also lower than that obtained for other Portuguese estuaries: 27 species in the Ria de Aveiro and 105 in the Sado estuary (Mucha and Costa, 1999), 30 in the Mondego estuary (Marques et al., 1993a) and 53 in the Ria Formosa (Sprung, 1994). A previous study conducted in similar habitats of the Tagus estuary (Rodrigues et al., 2006) also showed higher species richness (68 species) than that obtained in the present work. However, this study reported only 10 species as significantly contributing to the total abundance. In comparison with tropical mudflats, species richness of this type of habitat in temperate estuaries tends to be lower, whereas species abundances tend to be higher (Dittmann, 2000). The low number of species recorded in the present study may be related to the fact that the study area was small (different habitats within the estuary) in comparison with other studies, which often cover gradients through the whole estuarine system.

Although species richness was very low in the present study, the most common and abundant species, which dominate the intertidal macrobenthic community, were the same as those reported 

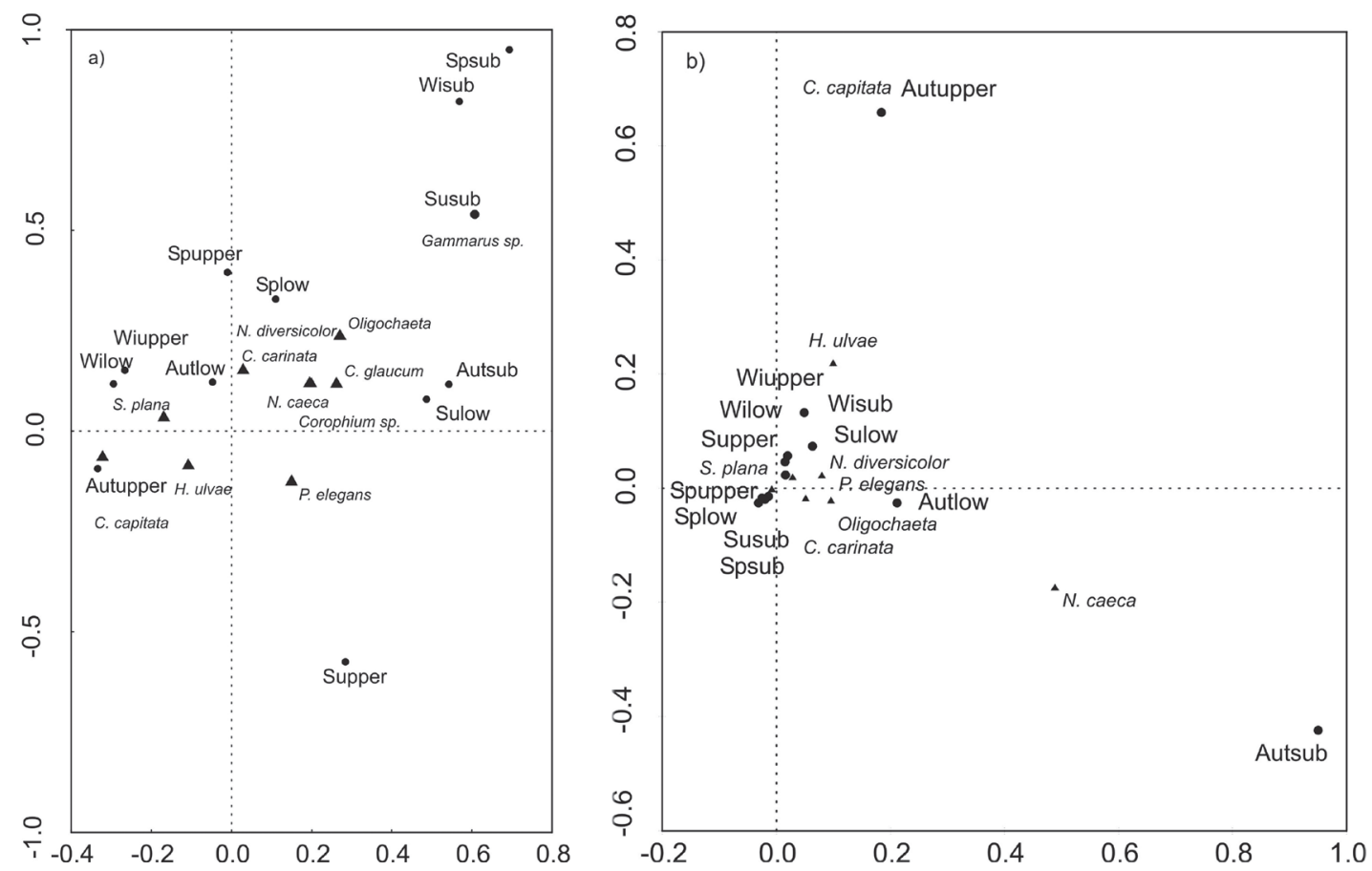

FIG. 5. - Correspondence analysis ordination diagrams for macrobenthic species density (a) and biomass (b) data. (upper, lower and sub refer to upper intertidal, lower intertidal and subtidal respectively. Sp, spring; Su, summer; Aut, autumn; Wi, winter)

in previous studies for this area, including mainly Scrobicularia plana, Cyathura carinata, Nereis diversicolor and Hydrobia ulvae (Rodrigues et al., 2006). A study of intertidal areas on the north bank of the Tagus estuary showed a comparable situation, with a higher number of identified taxa and the same dominating species within the community (Silva et $a l ., 2006)$. The main difference in comparison with our study was the high abundances of the polychaete Streblospio shrubsolii, one of the species known to be commonly associated with this type of community (Borja et al., 2004). The present work was conducted at a very specific and relatively small area on an intertidal mudflat and in subtidal adjacent areas of a sheltered branch of the Tagus estuary, and this might explain why this species was not found. Previous studies conducted in exactly the same area also failed to indicate $S$. shrubsolii as one of the dominant species in the community (Cardoso et al., 2008). According to Rodrigues et al. (2006), this species is widely distributed in the estuary but high abundances were only found in the northernmost part of the sampled area and always in the lower parts of the intertidal mudflat. This species' high density values were also obtained in a more exposed area on the north bank of the Tagus estuary and were mostly associated with its recruitment during the autumn (Silva et al., 2006).
Similar biomass values to those of the present study were previously recorded in this mudflat area of the Tagus estuary for the bivalve Scrobicularia plana, with this species representing almost $86 \%$ of the total biomass (Rodrigues et al., 2006).

The strong dominance of the overall macrobenthic assemblage by very few species is a common pattern in other intertidal areas, particularly in muddy sediments (Kalejta and Hockey, 1991; Guerreiro, 1998; Ysebaert and Herman, 2002). The macrobenthic community described in this study seems to be typical for the inner middle part of the estuaries, frequently occurring on muddy sand flat bottoms and well oxygenated waters, as reported by Borja et al. (2004). According to these authors, the main taxa associated with this community are the Oligochaeta group, the polychaetes Streblospio shrubsolii and Nereis diversicolor, the gastropod Hydrobia ulvae and the crustacean Cyathura carinata and Corophium spp. The polychaete Pygospio elegans, one of the most abundant species found in the present work, can also be characteristic of this type of estuarine community (Junoy and Viéitez, 1990).

Significant changes in the level of the depth/elevation gradient, especially considering the full range from the deep subtidal zone to the high intertidal, are known to have a pronounced effect on estuarine macrobenthic species distribution (Ysebaert et al., 2002). 
Among the few studies on this subject, for an estuary on the Belgium coast (Zeeschelde), Yasebaert et al. (2000) report a different pattern to that obtained in the present study, with higher species richness in the subtidal area than in the intertidal areas. However, these authors also report higher densities and biomass in the intertidal level. In the Mondego estuary (Portugal) a comparison between the macrobenthic communities from the intertidal and subtidal areas was performed, with higher species richness in the intertidal area (90 species) (Marques et al., 1993a) than the subtidal area (52 species) (Marques et al., 1993b).

Regarding the species density of this community, spatial variation clearly dominated over seasonal variation throughout the sampling period. This emphasises the key role played by this intertidal mudflat in the macrobenthic community, particularly during recruitment as density peaks (including a high number of juveniles) for all the species were recorded in this habitat. The same kind of pattern was obtained for the Douro estuary, where the spatial variation was found to be greater than the seasonal one, in terms of both environmental parameters and macrobenthic community structure (Mucha et al., 2005). A similar pattern in both benthic community structure and composition, with dominance of spatial over seasonal variability, was recently described for estuaries in North Carolina, USA (Hyland et $a l .$, 2004). Similar results were obtained in a study conducted in a tropical region, where variations recorded in the density of the most dominant taxa in mangrove and seagrass areas were mainly related to the type of habitat, not showing any pattern inherent to season (Sheridan, 1997).

Concerning seasonality, the macroinvertebrate community from the study area showed the usual pattern for macrobenthic organisms: a density increase from spring until autumn, with a decrease in abundance during the winter months (Marques et al., 1993a); Ysebaert et al., 2003; Chainho et al., 2006). This seasonal pattern seems to reflect the recruitment patterns of the different species, which usually takes place during spring and summer months. The highest species biomass values were obtained in spring, followed by a continuous decrease until winter, when the minimum values were reached. This is a common pattern for macrobenthic communities since most of the species show faster growth rates during spring months, when temperatures values increase (Beukema, 1974; Ysebaert et al., 2003).
One of the most abundant species from the macrobenthic community studied was the bivalve Scrobicularia plana, also a common and abundant one in other estuarine systems (Marques et al., 1993a; Sola, 1997; Chainho et al., 2006; Rodrigues et al., 2006; Silva et al., 2006). In the study area in the Tagus estuary, S. plana reached a density peak in November, differing from previous works that indicate recruitment for this species and consequent increase in its abundance between spring and summer months (Verdelhos et al., 2005). Nevertheless, a previous study conducted in the Tagus estuary reported recruitment for this species between summer and autumn (Silva et al., 2006). There was a rapid increase in biomass during the spring months. This confirms the results of previous works, which showed higher growth rates during the same period (Beukema, 1974; Verdelhos et al., 2005). Wanink and Zwarts (1993) concluded that tidal height also has a strong relation to the distribution of different age classes for this species: smaller individuals are found mainly in intertidal areas with longer emersion periods. This may explain the occurrence of smaller individuals in the upper part of the intertidal area, as shown in the present work.

The isopod Cyathura carinata was also one of the dominant species in the studied community. It had already been reported as one of the most abundant species on intertidal mudflat habitats (Marques et al., 1994; Ferreira et al., 2004). The seasonal density pattern obtained for this species is similar to those described in previous studies: highest values in late summer and a subsequent decrease until the following spring (Ferreira et al., 2004). This species recruits once a year, generally in the summer months (Marques et al., 1994; Ferreira et al., 2004). This agrees with results obtained in the present study. As was shown for the bivalve Scrobicularia plana, an increase in biomass also occurred for $C$. carinata in spring (Ferreira et al., 2004).

The polychaete Nereis diversicolor is a common species found on the intertidal mudflat habitats of most European estuaries (Abrantes et al., 1999; Cabral et al., 1999; Masero et al., 1999). As occurred in the present study, the density patterns for this species were also variable in a study conducted in the Ria de Aveiro (Abrantes et al., 1999). Despite the variations, in both cases the density of this species increased in spring, with considerably higher values in summer and a subsequent decrease in the autumn and winter months. Recruitment peaks for this species were 
not clearly visible, but according to previous works they may occur once a year, in spring or summer, or twice a year, when it has a wider reproduction period (Abrantes et al., 1999; Silva et al., 2006). Besides the variations in the recruitment processes of this species, there are also factors that may explain the variation in density patterns at a spatial level.

Results from the present work demonstrate the key role that intertidal mudflats in the Tagus estuary play for macroinvertebrate communities. Most species of this community seem to take advantage of the favourable conditions they can find in this specific type of habitat, as considerably higher density and biomass values are found there. According to França et al. (2008), the same intertidal mudflat also plays an important role for the nekton community of the Tagus estuary. The most abundant nekton species showed a marked seasonal pattern when using this habitat, with highest densities during the spring and summer months. Most of these density peaks reflected the recruitment of these species, which may also indicate that they can take advantage of the high abundance of prey in the mudflat, as the present study describes high densities of macroinvertebrates during this period. Long-term studies on these communities would be useful to assess their structure and dynamics and to detect inter- and intraannual fluctuations. Understanding these ecological patterns, particularly where spatial and/or temporal variation is great, also requires a comprehensive appreciation of the interactions of geomorphology, hydrology and climatology. Further studies on these intertidal mudflats and the communities that explore them are crucial and must take all these parameters into account in order to understand their structure, dynamics and functioning and their relationship with other estuarine habitats.

\section{ACKNOWLEDGEMENTS}

The authors would like to thank Fundação para a Ciência e a Tecnologia (FCT) for funding.

\section{REFERENCES}

Abrantes, A., F. Pinto and M.H. Moreira. - 1999. Ecology of the polychaete Nereis diversicolor in the Canal de Mira (Ria de Aveiro, Portugal): Population dynamics, production and oogenic cycle. Acta Oecol., 20(4): 267-283.

Bettencourt, A., I. Cruz, J.G. Ferreira, J.L. Costa, M.C. Silva and F.V. Gomes. - 2001. Ecossistemas aquáticos- estuários e águas costeiras. In: C.A. Aires and O. Borges. Plano nacional de água. Volume I - Introdução, caracterização e diagnóstico da situação actual dos recursos hídricos, pp:32 (7-II)-61 (7-II). INAG, Lisboa.

Bettencourt, A. and L. Ramos. - 2003. Estuários Portugueses. Instituto da Água.

Beukema, J.J. - 1974. Seasonal changes in the biomass of the macro-benthos of a tidal flat area in the Dutch Wadden Sea. Neth. J. Sea Res., 8(1): 94-107.

Boer, W.F. and H.H.T Prins. - 2002. The community structure of a tropical intertidal mudflat under human exploitation. ICES J. Mar. Sci., 59: 1237-1247.

Borja, A., F. Aguirrezabalaga, J. Martinez, C. Sola, L. GarciaArberas and M. Gorostiaga. - 2004. Benthic communities, biogeography and resources management. In: A. Borja, and M. Collins, Oceanography and Marine Environment of the Basque Country, pp. 455-492. Elsevier Oceanography. (Series 70). Elsevier, Amsterdam, The Netherlands.

Cabral, J.A., M.A. Pardal, R.J. Lopes, T. Múrias and J.C. Marques. - 1999. The impact of macroalgal blooms on the use of the intertidal area and feeding behaviour of waders (Charadrii) in the Mondego estuary (west Portugal). Acta Oecol., 20: 417-427.

Cabral, H.N. - 2000. Comparative feeding ecology of sympatric Solea solea and Solea senegalensis, within the nursery areas of the Tagus estuary, Portugal. J. Fish Biol., 57: 1550-1562.

Cabral, H.N., M.J. Costa and J.P. Salgado. - 2001. Does the Tagus estuary fish community reflect environmental changes? Clim. Res., 18: 119-126.

Calvário, J. - 1982. Estudo ambiental do estuário do Tejo: povoamentos bentónicos intertidais (substratos móveis). CNA TEJO 19, Rel 18, Comissão Nacional do Ambiente, Lisboa, Portugal.

Cardoso, I., J.P. Granadeiro and H.N. Cabral. - 2008. Benthic prey quantity and quality in the main mudflat feeding areas of the Tagus estuary: implications for bird and fish populations. Cienc. Mar., 34(3):283-296.

Chainho, P., J.L. Costa, M.L. Chaves, M.F. Lane, D.M Dauer and M.J. Costa. - 2006. Seasonal and spatial patterns of distribution of subtidal benthic invertebrate communities in the Mondego River, Portugal - a poikilohaline estuary. Hydrobiologia, 555: 59-74.

Costa, M.J. and A. Bruxelas. - 1989. The structure of fish communities in the Tagus Estuary, Portugal, and its role as a nursery for commercial fish species. Sci. Mar., 53(2-3): 561-566.

Costa, M.J. and H.N. Cabral. - 1999. Changes in the Tagus nursery function for commercial fish species: some perspectives for management. Aquat. Ecol., 33: 287-292.

Costanza, R., R. Arge, R. de Groot, S. Farber, M. Grasso, B. Hannon, K. Limburg, S. Naeem, R.V. O'neill, J. Paruelo, R.G. Raskin, P. Sutton and M. van den Belt. - 1997. The value of the world's ecosystem services and natural capital. Nature, 387: 253-260.

Dewicke, A., A. Cattrijsse, J. Mees and M. Vincx. - 2003. Spatial patterns of the hyperbenthos of subtidal sandbanks in the southern North Sea. J. Sea Res., 49: 27-45.

Dittmann, S. - 2000. Zonation of benthic communities in a tropical tidal flat of north-east Australia. J. Sea Res., 43: 33-51.

Dolbeth, M., M.A. Pardal, A.I. Lillebø, U. Azeiteiro and J.C. Marques. - 2003. Short and long-term effects of eutrophication on the secondary production of an intertidal macrobenthic community. Mar. Biol., 143: 1229-1238.

Elliott, M. and C.J.M. Taylor. - 1989. The production ecology of the subtidal benthos of the Forth Estuary, Scotland. Sci. Mar., 53: 531-541.

Elliott, M. and F. Dewailly. - 1995. The structure and components of European estuarine fish assemblages. Neth. J. Aquatic Ecol., 29: $397-417$

Elliott M. and K.L. Hemingway. - 2002. Fishes in Estuaries. Blackwell Science.

Farinha, J., L. Costa, A. Trindade, P. Araújo and E. Silva. - 2001. Zonas Húmidas Portuguesas de Importância Internacional. Sítios Inscritos na Convenção de Ramsar, $1^{\text {a }}$ ed. Lisboa. Instituto da Conservação da Natureza, 88 p.

Ferreira, S.M., M.A. Pardal, A.I. Lillebø, P.G. Cardoso and J.C. Marques. - 2004. Population dynamics of Cyathura carinata (Isopoda) in a eutrophic temperate ecstuary. Estuar. Coast. Shelf Sci., 61: 669-677.

França, S., M.A. Pardal and H.N. Cabral. - 2008. Mudflat nekton assemblages in the Tagus estuary (Portugal): distribution and 
feeding patterns. Sci. Mar., 72(3): 591-602.

Frontier, S. - 1983. Stratégies d'Échantillonage en Écologie. Masson, Paris.

Guerreiro, J. - 1998. Growth and production of the bivalve Scrobicularia plana in two southern European estuaries. Vie Milieu, 48: 121-131.

Heck, K.L., K.W. Able, C.T. Roman and M.P. Fahay. - 1995. Composition, abundance, biomass and production of macrofauna in a New England estuary: comparisons among eelgrass meadows and other nursery habitats. Estuaries, 18(2): 379-389.

Hyland, J.L., W.L. Balthis, M. Posey, C.T. Hackney and T. Alphin. - 2004. The soft-bottom macrobenthos of North Carolina estuaries. Estuaries, 27: 501-514.

Junoy, J. and J.M. Viéitez. -1990. Macrozoobenthic community structure in the Ria de Foz, an intertidal estuary (Galicia, Northwest Spain). Mar. Biol., 107: 329-339.

Kalejta, B. and P.A.R. Hockey. - 1991. Distribution, abundance and productivity of benthic invertebrates at the Berg River Estuary, South Africa. Estuar. Coast. Shelf Sci., 33: 175-191.

Laine, A.O. - 2003. Distribution of soft-bottom macrofauna in the deep open Baltic Sea in relation to environmental variability. Estuar. Coast. Shelf Sci., 57: 87-97.

Marques, J.C., L.B. Rodrigues and A.J.A. Nogueira. - 1993a. Intertidal macrobenthic community structure in the Mondego estuary (Western Portugal): reference situation. Vie Milieu, 43 (2-3): 177-187.

Marques, J.C., P. Maranhão and M.A. Pardal. - 1993b. Human impact assessment on the subtidal macrobenthic community structure in the Mondego estuary (western Portugal). Estuar. Coast. Shelf Sci., 37: 403-419.

Marques, J.C., I. Martins, C. Teles-Ferreira and S. Cruz. - 1994. Population dynamics, life history, and production of Cyathura carinata (Krøyer) (Isopoda: Anthuridae) in the Mondego Estuary, Portugal. J. Crust. Biol., 14: 258-272.

Masero, J.A., M. Pérez-González, M. Basadre and M. Otero-Saavedra. - 1999. Food supply for waders (Aves: Charadrii) in an estuarine area in the Bay of Cádiz (SW Iberian Peninsula). Acta Oecol., 20: 429-434.

McLusky, D.S. - 1989. The estuarine ecosystem. Blackie \& Son, Glasgow and London. Chapman \& Hall, New York.

Melville, A.J. and R.M. Connolly. - 2005. Food webs supporting fish over subtropical mudflats are based on transported organic matter not in situ microalgae. Mar. Biol., 148: 363-371.

Michaelis, H., H. Fock, M. Grotjahn and D. Post. - 1992. The status of the intertidal zoobenthic brackish water species in estuaries of the German bight, Neth. J. Sea Res., 30: 201-207.

Moreira, F. - 1999. On the use by birds on intertidal areas of the Tagus estuary: implications for management. Aquat. Ecol., 33: 301-309.

Morrisey, D.J., G.A. Skilleter, J.I. Ellis, B.R. Burns, C.E. Kemp and K. Burt. -2003. Differences in benthic fauna and sediment among mangrove (Avicennia marina var. australasica) stands of different ages in New Zealand. Estuar. Coast. Shelf Sci., 56: 581-592.

Morrison, M.A., M.P. Francis, B.W. Hartill and D.M. Parkinson. - 2002. Diurnal and tidal variation in the abundance of the fish fauna of a temperate tidal mudflat. Estuar. Coast. Shelf Sci., 54: 793-807.

Mucha, A.P. and M.C. Costa. - 1999. Macrozoobenthic structure in two Portuguese estuaries: relationship with organic enrichment and nutrient gradients. Acta Oecol., 20: 363-376.
Mucha, A.P., M.T. Vasconcelos and A. Bordalo. - 2005. Spatial and seasonal variations of the macrobenthic community and metal contamination in the Douro estuary (Portugal). Mar. Environ. Res., 60: 531-550.

Odum, E.P. - 1983. Basic Ecology. Saunders College Publishing, Philadelphia.

Reise, K. - 1985. Tidal flat Ecology. Springer, Berlin.

Rodrigues, A.M., S. Meireles, T. Pereira, A. Gama and V. Quintino. - 2006. Spatial patterns of benthic macroinvertebrates in intertidal areas of a Southern European estuary: the Tagus, Portugal. Hydrobiologia, 555: 99-113.

Sheridan, P. - 1997. Benthos of adjacent mangrove, seagrass and non-vegetated habitats in Rookery Bay, Florida, USA. Estuar. Coast. Shelf Sci., 44: 455-469.

Silva, G., J.L. Costa, P.R. Almeida and M.J. Costa. - 2006. Structure and dynamics of a benthic invertebrate community in an intertidal area of the Tagus estuary, western Portugal: a six year data series. Hydrobiologia, 555: 115-128.

Sola, J.C. - 1997. Reproduction, population dynamics growth and production of Scrobicularia plana da Costa (Pelecypoda) in the Bidasoa estuary, Spain Neth. J. Aquatic Ecol., 30(4): 283-296.

Sprung, M. - 1994. Macrobenthic secondary production in the intertidal zone of Ria Formosa - a lagoon in southern Portugal. Estuar. Coast. Shelf Sci., 38: 539-558.

Ter Braak, C.J.F. and P. Smilauer. - 2002. CANOCO Reference Manual and CanoDraw for windows User's Guide: Software for Canonical Community Ordination. Version 4.5. Microcomputer Power, Ithaca, New York, USA.

Verdelhos, T., J.M. Neto, J.C. Marques and M.A. Pardal. - 2005. The effect of eutrophication abatement on the bivalve Scrobicularia plana Estuar. Coast. Shelf Sci., 63: 261-268.

Vinagre, C., S. França and H.N. Cabral. - 2006. Diel and semilunar patterns in the use of an intertidal mudflat by juveniles of Senegal sole, Solea senegalensis. Estuar. Coast. Shelf Sci., 69(1-2): 246-254.

Wanink, J.H and L. Zwarts. - 1993. Environmental effects on the growth rate of intertidal invertebrates and some implications for foraging waders. Neth. J. Sea Res., 31(4): 407-418.

Ysebaert, T., P. Meire, J. Coosen and K. Essink. - 1998. Zonation of intertidal macrobenthos in the estuaries of Schelde and Ems. Aquat. Ecol., 32: 53-71.

Ysebaert, T., L. De Neve and P. Meire. - 2000. The subtidal macrobenthos in the mesohaline part of the Schelde Estuary (Belgium): influenced by man? J. Mar. Biol. Assoc. U.K., 80: 587-597.

Ysebaert, T. and P.M.J. Herman. - 2002. Spatial and temporal variation in benthic macrofauna and relationships with environmental variables in an estuarine, intertidal soft-sediment environment. Mar. Ecol. Prog. Ser., 244: 105-124.

Ysebaert, T., P. Meire, P.M.J. Herman and H. Verbeek. - 2002. Macrobenthic species response surfaces along estuarine gradients: prediction by logistic regression. Mar. Ecol. Prog. Ser., 225: 79-95.

Ysebaert, T., P.M.J. Herman, P. Meire, J. Craeymeersch, H. Verbeek and C.H.R. Heip. - 2003. Large-scale spatial patterns in estuaries: estuarine macrobenthic communities in the Schelde estuary, NW Europe. Estuar. Coast. Shelf Sci., 57: 335-355.

Scient. ed.: R. Sardà.

Received September 4, 2007. Accepted October 2, 2008.

Published online March 4, 2009. 